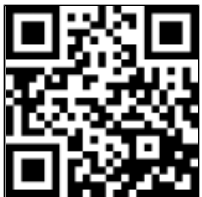

Editor's choice

free content

${ }^{1}$ Academic Department of Military Surgery and Trauma, Royal Centre for Defence Medicine, ICT Centre, Institute of Research and Development, Birmingham, UK

${ }^{2}$ Defence Science and Technology Laboratory, Salisbury, Wiltshire, UK

\section{Correspondence to} W G P Eardley, Academic Department of Military Surgery and Trauma, Royal Centre for Defence Medicine, ICT Centre, Institute of Research and Development, Birmingham Research Park, Vincent Drive, Birmingham B15 2SQ, UK; willeardley@doctors. org.uk

Received 19 March 2013 Accepted 21 March 2013

To cite: Eardley WGP Watts SA, Clasper JC. J R Army Med Corps 2013;159:73-83.

\title{
Modelling for conflict: the legacy of ballistic research and current extremity in vivo modelling
}

\author{
William G P Eardley, ${ }^{1}$ S A Watts, ${ }^{2}$ J C Clasper ${ }^{1}$
}

\section{ABSTRACT}

Extremity ballistic injury is unique and the literature intended to guide its management is commonly misinterpreted. In order to care for those injured in conflict and conduct appropriate research, clinicians must be able to identify key in vivo studies, understand their weaknesses and desist the propagation of miscited and misunderstood ballistic dogma. This review provides the only inclusive critical overview of key studies of relevance to military extremity injury. In addition, the non-ballistic studies of limb injury, stabilisation and contamination that will form the basis from which future small animal extremity studies are constructed are presented. With an awareness of the legacy of military wound models and an insight into available generic models of extremity injury and contamination, research teams are well placed to optimise future military extremity injury management.

\section{INTRODUCTION}

Combat wounding is characterised by disabling extremity injury, and $70 \%$ of war wounds involve the limbs. ${ }^{12}$ Mechanism is key: short duration, high-energy transfer explosions with fragmentation cause $75 \%$ of extremity war wounds ${ }^{3}$ and infection, a source of significant morbidity in survivors of combat, ${ }^{4-7}$ is associated with these injuries.

While the Lower Extremity Assessment Project, a multicentre prospective outcome study of significant limb injury, reports outcomes for limb salvage and amputation, ${ }^{8}$ it is an observational civilian study uncontrolled for initial injury management. Overall, ballistic trauma is notable for the absence of its clinical evidence base. Inability to control and stratify injuries, treatment or follow-up compromises study methods supporting the need for in vivo experimentation to further the understanding of war wounding.

This review provides the only critique of key models in the study of combat relevant extremity injury; it highlights inadequacies in existing animal studies that limit their application to combat extremity injury and will guide future model design.

\section{METHOD}

Combat wounding is rarely isolated to a single tissue and compound injury of bone and soft tissues predominates. Similarly, seldom are such wounds free of debris or organisms. In order to represent this and present the findings of this review in a structured fashion, in vivo models are categorised according to animal type and then discussed further with regard to fracture, soft tissue injury and infection.

An electronic search of the Medline database using the PubMed search engine limited to

\section{Key messages}

Extremity ballistic injury is unique and demands individual care, based on clinical and in vivo research.

- Ballistic injury literature is often misinterpreted: a situation which propagates an often dogmatic approach to war surgery.

- Large animal models of simple projectile injury must be placed in context with and contrasted to modern combat injury patterns.

- Civilian small animal models of injury and infection have application to military injury modeling although are limited in their exploitation of contaminated soft tissue injury.

- A need exists to further develop military specific, contaminated soft tissue small animal soft tissue models.

- With an awareness of both large and small animal ballistic and extremity trauma models, military surgeons are in a better position to accurately interpret pertinent literature and optimize patient care.

manuscripts published in English until July 2012 was performed. Medical Subject Headings of Wounds, Penetrating, Forensic Ballistics, Models, Animal, Fractures, Bone and Extremities and Boolean operators, were used to construct a search strategy ${ }^{9}$ and although the nature of the studies reviewed preclude systematic review or meta-analysis, the outcome of retrieved abstracts is presented (Figure 1). Retrieved abstracts were analysed for relevance and full text papers obtained. Articles initially missed in this search were obtained from manual searching of the bibliography of retrieved studies.

In order to ensure only articles relevant to the representation and investigation of ballistic extremity trauma were reviewed, a considerable number were excluded from further analysis according to the exclusion criteria in Box 1.

\section{PORCINE MODELS OF BALLISTIC INJURY}

The animal of choice for physiological resuscitation studies, ${ }^{10}$ porcine models, are used to investigate management options in the blast injured casualty. ${ }^{1-21}$ To study gunshot wounding (GSW), however, anatomical projectile interaction with tissues is key in the choice of model. Again, swine are historically the most popular choice due to similarity in tissue architecture and scale to the human. The impact of muzzle velocity, the stimulus for much porcine modelling to 


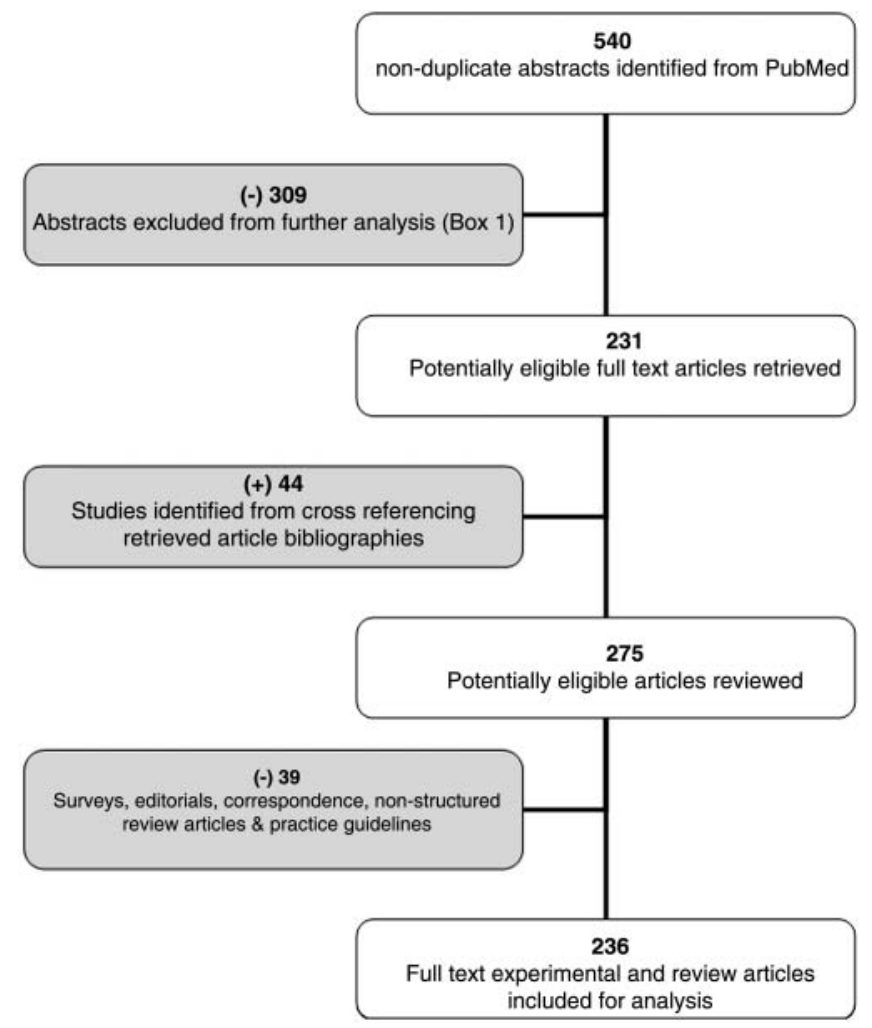

Figure 1 Flowchart of article identification.

follow, was highlighted in a series of clinical papers by DeMuth, ${ }^{22-26}$ attesting that 'velocity makes the difference' 23 in GSW and that killing power is determined by the velocity at impact $^{22}$ based on changes in wounding patterns from the Vietnam War following the issue of a new rifle to the US troops. $^{27} 28$ The $7.62 \mathrm{~mm}$ round fired from the M14 rifle was replaced by the lighter, smaller and faster $5.56 \mathrm{~mm}$ ammunition for the M16. Increased muzzle velocity was presumed to result in greater tissue trauma although it has, in many wounds, the opposite effect. In wounds with short tracts, the smaller, faster bullets were likely to pass through tissue intact. Only in those cases where the bullet was retarded or had significant tract length were devastating injuries $\operatorname{seen}^{29}$ although investigators of the post-Vietnam era, however, made muzzle velocity central to their in vivo porcine wounding hypotheses.

Velocity as a variable in wounding is not new, as demonstrated by Kocher's theory ${ }^{30}$ of hydrodynamic projectile-tissue interaction: the pressure wave created when a projectile contacts a medium of different density. ${ }^{31}$ This underlies many animal models of GSW, including the Swedish Missile Trauma model (SMTM), ${ }^{32}$ a series of experiments on the legs of Swedish

\section{Box 1 Exclusion criteria for further analysis of retrieved} abstracts

- Non-extremity military ballistic injury articles

- Exclusively in vitro studies

- Clinical studies of extremity injury management

- In vivo models of simple skin wounding and healing

- Non-extremity in vivo models
Landrace pigs. In earlier versions, ${ }^{33}$ standard weaponry are used although later, smooth spheres fired into the pigs legs ${ }^{34} 35$ were correlated with simulant media on a hypothesis that it is solely the conversion of deposited kinetic energy which has potential and therefore may be responsible for tissue damage. This philosophy, concentrating only on energy deposition generated through muzzle velocity, disregards the effects of the projectile physically passing through and damaging soft tissue and bone.

This SMTM method is used to investigate local mechanical $^{33} 36$ and metabolic ${ }^{37-41}$ effects of projectiles, the influence of trajectory length, ${ }^{42}$ timing and extent of debridement ${ }^{34}$ and the influence of antibiotics. ${ }^{35}$

The SMTM has limitations, which have come to signify the divide in the scientific community over the concepts of muzzle velocity and energy transfer and the impact of both on wounding. First, little attention is paid in the SMTM to fragmentation and its effect on tissues. Berlin $e t a l^{33}$ report that damaged bullets resulted in 'complicated' or high severity wounds regardless of initial velocity. Despite this, the authors hypothesise that it is actually the impact of projectile velocity that influences the amount of nonviable tissue. Second, the use of simulant media further threatens their findings. A non-elastic (gelatin) tissue stimulant is used rendering it impossible to distinguish a temporary cavity (of lesser injurious extent) from the crushing tissue loss of the permanent cavity. The blocks are not calibrated following preparation and thus any variance introduced through non-standardised heating of the gelatin will affect the results, further preventing generalisation of kinetic energy transfer results to live tissue. ${ }^{43}$

Further limitations include the use of steel spheres which do not yaw, nutate or fragment and hence the non-reproducible, non-uniform impact surface and the 'secondary projectile' effect is neglected. Animals in which projectiles hit bone were excluded from analysis, ${ }^{34} 41$ despite the relationship among 
fragmentation, fracture and wound severity identified at the outset of the model. ${ }^{33}$ These studies therefore have limited similarity to current ballistic injury patterns. Following criticism of the SMTM, the characterisation of wounds by muzzle velocity $^{44} 45$ and the practice of basing debridement on energy transfer came into question as investigators brought into consideration the effect of bullets and other projectiles physically interacting with tissues. ${ }^{46}$

Fackler and his colleagues reported a series of combined in vivo and tissue substitute studies investigating standard munitions in porcine models. In contrast to the SMTM, the models of Fackler et $a l^{47-49}$ are focused on the effect of bullet deformation on the wound profile. Using a porcine model they demonstrated that the wounding profile was strongly correlated to the design and behaviour of the projectile within tissue, related to its trajectory, ${ }^{49} 50$ the elasticity of the organs in its proximity ${ }^{47}$ and ultimately to its fragmentation. ${ }^{51} 52$ Assessment of the tract through tissue and gelatin blocks revealed that disruption from fragmenting bullets is significant and that fascial decompression often occurs at wounding. In the presence of antibiotic cover, wound excision did not improve time to healing in simple, short tract wounds. ${ }^{53}$

In contrast to guiding debridement by kinetic energy, ${ }^{33}$ Fackler et al proposed that projectile fragmentation should guide tissue excision, a hypothesis corroborated by Tikka et al. $^{54}$ In contrast to other Scandinavian studies, Tikka's group used standard weaponry and of the munitions fired, the $5.56 \mathrm{~mm}$ round underwent greater fragmentation, was associated with greater energy transfer and necessitated the resection of up to twice as much tissue than the larger calibre projectiles. This was achieved by a bullet of less than half the mass $(3.6 \mathrm{~g})$ of the two greater calibre rounds $(8 \mathrm{~g})$. The lower mass of the $5.56 \mathrm{~mm}$ round contributed to its initial impact energy being $20 \%$ less than the M62 or AK47 ammunition, although its transferred energy was $276 \%$ greater. The key finding of these models, therefore, in contrast to the SMTM, is that the influence of bullet mass and velocity is of little consequence in comparison to the terminal behaviour of the round.

While Fackler et al present evidence more generalisable to the clinical setting than that of the SMTM, the use of smooth projectiles and 'simple' low energy transfer wound models should not be discounted. Although acknowledged to be less representative of compound tissue trauma, they do have relevance to injury by multiple small fragments. In the models of both Bowyer $e t a l^{55}$ and Mellor et al, ${ }^{56}$ uniform projectiles are used in a low-energy transfer wounding, avoiding bone and vessels, producing short projectile tracts. These wounds are then used to assess the impact of antibiotic administration, demonstrating that for the selected wound profile, surgical intervention is less likely to be required. ${ }^{57-59}$

More recently, porcine modelling has moved towards examining the effects of injury distant to the projectile. As with other areas of ballistics, misunderstanding of shock waves leads to confusion. The shock wave is sonic pressure that results from the bullet striking tissue. Travelling at the speed of sound (ie, faster than the speed of the bullet), it passes through tissue ahead of the projectile. Cavitation is a separate entity caused by the bullet physically striking tissue and occurs in its wake. ${ }^{31}$ Suneson et al demonstrated in vivo and in vitro shock wave injury thus highlighting local, regional and distant injuries resulting from sonic pressure waves. Stigmata of microscopic damage to central and peripheral nerves occurred at a distance and was therefore not attributable to the effects of either the permanent or temporary cavities of the projectile. ${ }^{6061}$
Attribution of tissue damage to the sonic wave as opposed to the effects of temporary cavitation has attracted considerable debate. Fackler and Peters are vociferous in their critique and both in correspondence with Suneson $e t a l^{62}$ and in a later published review dismiss injury due to the effects of the sonic wave as myth. ${ }^{63}$ The arguments used against acceptance of injury by the sonic wave are suspect. Fackler cites comparison with a previously reported animal model ${ }^{53}$ as proof that distant injury does not occur but the methodology of the two experiments however is disparate and it is impossible to generalise from the work of Fackler $e t a l^{53}$ to that of Suneson et $a l^{6061}$ who make the point that distant injury occurred only at a microscopic level.

Fackler $e t \mathrm{al}^{53}$ state that in one of their studies 'an area of the thigh with the gunshot wound was sectioned for histological study'. This was in essence a study of local (thigh) tissue effects in which no evidence of distant injury was sought. It is difficult therefore to accept this as experimental proof that the work of Suneson et al is flawed. Similarly, Fackler and Peters cite the absence of distant injury seen in the Vietnam conflict. Using data from 1400 GSWs they remark that 'there were no cases of bones being broken, or major vessels torn, that were not hit by the penetrating bullet. ${ }^{62}$ Again, comparing such macroscopic, local wound evaluation to a controlled animal experiment performed at a distant microscopic level is questionable. In addition, subsequent interrogation of the Vietnam data ${ }^{64}$ reveals Fackler's interpretation to be biased as 'the database contains at least one possible example of this phenomenon' ${ }^{64}$ referring to the influence of pressure waves on nerve tissue injury.

Thus, it can be seen that far from refuting the possibility of distant injury occurring secondary to GSW, these data suggest that such a mechanism may exist. While often contradictory, a large body of experimental evidence exists for the interaction among projectiles, tissue or its substitute.

In addition, increasing evidence exists for trauma distant to the projectile in extremity models not attributable to cavitation phenomena. This is of particular relevance in combat injuries seen as a result of explosion.

\section{NON-PORCINE MODELS OF GSW}

The damaging potential of high-velocity bullets was assumed, as with the SMTM, to be so great that they exploded on contact with tissues $^{65}$ and the teaching that widespread debridement should be carried out for high-velocity gunshot wounds resulted. Often incorrectly cited, this erroneous dogma should actually be attributed to Rybeck ${ }^{66}$ who proposed that highvelocity GSWs resulted in a temporary cavitation effect 30 times the diameter of the bullet entering the tissue, but more importantly that tissue within this zone would not survive. He used a canine model in which a smooth spherical projectile was shot through the medial hind leg of dogs and concluded that:

...the temporary cavity following the high velocity missile appeared to affect the tissue as markedly as the contusion trauma.

These findings can explain the clinical experience that tissues which have been subjected to the formation of the temporary cavity after a high velocity missile will not survive.

This is the paragraph of text which erroneously has most influenced the management of wounding by gunshot with such a debridement equating to the removal of a mass of tissue some $23 \mathrm{~cm}$ in diameter for all presumed high-velocity wounds. ${ }^{63}$ The concept that huge debridement is mandatory sprang from this canine model and continues to influence surgical doctrine. Of note, Rybeck's is a non-recovery model so that none of the dogs were allowed to recover from injury to provide clinical 
evidence to support the histological analysis that temporary cavitation led to such marked tissue destruction.

Contrary to the method of Rybeck, ${ }^{66}$ evidence can be found for lack of significant tissue loss and apparent healing from high-velocity wounding in non-porcine recovery models. In an ovine GSW model, Hopkinson and Watts ${ }^{67}$ found that damage to the tissues was confined to a small area around the projectile path. No surgery was performed and the animals recovered and ceased limping by the fourth day. The authors concluded that it would appear from the results presented here that the less severe wounds of skeletal muscle, particularly if there is no damage to major blood vessels, might heal spontaneously.' This finding that simple GSW, regardless of muzzle velocity, follow an uncomplicated path to healing is corroborated elsewhere in a ${\text { caprine } \text { model }^{68} \text { and also in a development }}^{69-71}$ of the ovine model of Hopkinson and Watts. ${ }^{67}$

Of note, however, is that these studies ${ }^{69-71}$ then go on to introduce the deliberate infection of such simple wounds. In contrast to the recovery of the health of animals without surgical intervention or antibiotics, in animals with wounds complicated by gas gangrene, no untreated animals survived and surgery had no impact on outcome. The administration of intramuscular penicillin, however, prevented gangrene and was more effective than either wound incision or excision.

Irrefutable evidence of recovery from simple high-velocity GSW in animal models thus exists and it is latterly acknowledged that the requirement for widespread tissue excision is a myth. ${ }^{72} 73$ It is concerning therefore that permanent tissue damage 30 times the size of the projectile and radical debridement remains quoted in established literature. ${ }^{74-77}$

Debridement based solely on muzzle velocity is flawed, but it is important to note the lack of contamination in the majority of studies and the clinician must balance excision of tissue due to projectile passage with that required to reduce the burden of contaminating organisms. It is the combination of these processes that guide debridement, not purely the speed at which the bullet travels prior to injury.

\section{NON-PROJECTILE LARGE ANIMAL EXTREMITY INJURY MODELS}

The porcine models involve injury to the extremity through passage of a projectile. Other militarily relevant large animal models have investigated extremity trauma in the absence of projectile injury. External fixator pin contamination and the impact on subsequent intramedullary nailing are the subject of a series of experiments by Clasper $e t a l^{78-80}$ in an ovine model of importance due to the preponderance of temporising external fixation followed by late definitive stabilisation in this population. In a study of pin sites contaminated with Staphylococcus aureus, all tracts became infected in addition to all of the contiguously sited but uncontaminated control pins. This model was subsequently used to demonstrate the role in infection of fluid accumulation at the pin-bone interface ${ }^{80}$ and intramedullary nailing in the presence of infected external fixator pin tracks. ${ }^{79}$ Lack of fracture in the model of Clasper $e t a l^{80}$ was addressed in a modification by Hill and colleagues demonstrating the morbidity associated with early intramedullary nailing of heavily contaminated tibial fractures despite debridement and antibiotic use. ${ }^{81}$

Osteomyelitis is also addressed in caprine models and the goat is chosen by Curtis $e t a l^{82}$ for their recovery study of open, $S$ aureus contaminated, tibial fracture management. The results of this work corroborate those from the ovine models of both Clasper's and Hill's groups with regard to infection risk in early intramedullary nailing of open fractures and also illustrate the benefits of increasing animal size in extremity trauma research. Standard surgical approaches and implants are used with only slight modifications.

The limitation of this study is its short time period with the inability to draw conclusions regarding long-term outcome of the different fixation strategies, especially in terms of clinically apparent infection or the impact this may have on fracture union.

Further exploring treatment modalities for open fractures, Svoboda et al $^{83}$ created a militarily relevant bioluminescent musculoskeletal wound model to perform a comparison of bulb syringe and pulsed lavage irrigation. This model represented a true experimental compound extremity injury and is the basis for a number of further studies using Pseudomonas species and $S$ aureus $^{84-88}$ including the experimental evaluation of topical negative pressure wound therapy augmented with silver dressings. ${ }^{89} 90$

While allowing for experimental manipulation of variables affecting early operative interventions in limb trauma, these studies are all of short duration and it would be beneficial to extend the study period to assess longer term outcomes, particularly with regard to the establishment of chronic osteomyelitis or the effect of model manipulation on fracture union.

Where the caprine studies benefit most compared to small animal models as highlighted by Salgado et $a l^{91}$ and Curtis et $a l^{82}$ is their comparative size in terms of osteology and ability to use standard osteosynthesis techniques and instruments. This comparison is not limited to internal fixation and a number of studies have used goats as experimental models for the study of external fixation. ${ }^{92-96}$

Internal and external fixation for fracture management, debridement and wound care and wound profiling have therefore all been investigated in vivo in large animals. Emphasis on muzzle velocity and the implication of energy transfer and debridement on this premise are highlighted in early porcine models alongside more compelling evidence of injury far distant to the projectile's path. Infection as a key component in extremity wounding is similarly noted.

An awareness of these studies and an understanding of those that have erroneously influenced modern wound care is essential to military surgeons and in particular those designing contemporary experimental models of extremity wounding.

\section{SMALL ANIMAL MODELS OF RELEVANCE TO MILITARY EXTREMITY INJURY}

Large animals have advantages in terms of similarity of physiology, surgical approach, bone structure and ease of implant instrumentation over smaller animals. Inherent in the use of such larger animals are significant husbandry and welfare issues associated with using more sentient animals for scientific research. Researchers are beholden to use as few animals, of least sentience, as possible in a responsible manner in accordance with the principles of replacement, refinement and reduction. ${ }^{97} 98$ Whereas complete replacement of experimental models with non-animal alternatives may not be plausible, the use of smaller animals of least sentience must be the aim.

Traditionally, models of fracture healing and instrumentation involved large animals and, in particular, the sheep tibia. ${ }^{99-101}$ The advent of gene targeting and significant advances in the evolution of osteosynthesis implants for small animals however has occasioned a move away from large animal models towards lesser sentient, easier housed, genetically manipulated rodents and rabbits. 
Murine models of extremity injury and infection

Examples of fracture initiation, stabilisation and healing are available in isolation in rats and mice. ${ }^{102-125}$ Muscle trauma in murine models is less well investigated and where performed is dominated by closed injury ${ }^{126-137}$ with limited relevance to military extremity trauma. While a minority of controlled, reproducible open muscle injury models are reported, ${ }^{138} 139$ the majority of methods use uncontrolled manual application of crushing forceps ${ }^{140-145}$ to the muscle belly with considerable variability. Infection modelling in the murine extremity models is also limited in scope, detailing primarily osseous critical defect or implant related infection in the rat. ${ }^{16-163}$ Similarly, soft tissue contamination models are limited. ${ }^{164} 165$

\section{Guinea pig models of extremity injury and infection}

The guinea pig is notably the animal used by Koch to establish the causative link between organism and disease. ${ }^{166}{ }^{167}$ In addition, susceptibility to pyogenic staphylococcal infection ${ }^{168}$ makes it of relevance to extremity studies both of wounding and prosthesis infection. Although the guinea pig demonstrates advantages of increased size over murine species while sharing their benefits in terms of economy of husbandry, there are drawbacks to their use. They are more expensive and do not offer the same potential for gene deletion technology as is available in the mouse.

In addition, as with the murine models, options for osteosynthesis and fracture modelling are less well established and impart considerable technical and logistic demands on the researcher. Unlike the murine models, fracture studies are limited with only one contemporary biomechanical study of fracture healing with rudimentary intramedullary stabilisation. ${ }^{169}$ Similarly, the animal is not routinely used to investigate osteomyelitis, with only one experimental assessment of a contaminated, open fracture. ${ }^{170}$

Although fracture and osteomyelitis models are limited in the animal, the experimental investigation of soft tissue infection and wounding is well established in guinea pigs. As the landmark study of Koch influenced the approach to disease causation, similarly the guinea pig contaminated wound model of Friedrich has had significant impact on the approach to extremity wounding and is the historical basis for an emergent approach to open fracture management. ${ }^{171}$

While numerous such guinea pig models of wounding and infection exist, they are not representative of contaminated extremity injury. Models involving incisional or lacerated wounds created on the flanks or paraspinal region of the animal with or without additional uncontrolled muscle crush through application of artery forceps characterise these studies. ${ }^{168-180}$

Reproducible, controlled tissue trauma does not feature in these models and none involve the limbs.

\section{Rabbit models of extremity injury and infection}

Benefiting from increased osseous dimensions while maintaining the relative ease of husbandry, the rabbit is an established animal model for fracture healing and orthopaedic implant investigation. Compared with the rat or mouse, however, soft tissue trauma is less well modelled in this animal.

The rabbit tibia has been extensively modelled in both open and closed fracture initiation. ${ }^{181-187}$ Stabilisation of fractures has also been reported using relative stability fixation and more advanced osteosynthesis. Early, rotationally unstable Kirschner wire intramedullary fracture fixation ${ }^{188-190}$ has been surpassed by rotationally stable interlocked nails. ${ }^{191}$ The dynamic compression plate, synonymous with fracture osteosynthesis, has also been modelled on the rabbit and of note is reported in an early study documenting primary bone healing in rabbit tibiae. ${ }^{185}$ This study of Rahn et al is significant in demonstrating the process of haversian remodelling in rabbit fracture healing similar to that in adult human bone. This contrasts the rabbit as a bone healing model to the available murine models, which demonstrate limited similarity to adult primary bone healing.

Infection of rabbit bone has been modelled more extensively than any other. It is also notable for rudimentary investigation of wound infection in the Vietnam conflict and is thus explored in greater detail. Simple osteomyelitis models were first developed in the rabbit although they were characterised by failure to produce progressive disease and, in addition, were associated with significant mortality. ${ }^{192-194}$ Norden and Kennedy ${ }^{195}$ identified the lack of long term osteomyelitis models in their modification of the work of Scheman et al. ${ }^{192}$ Percutaneously administering sclerosant and $S$ aureus into the proximal tibial metaphysis of New Zealand white rabbits, they introduced the 'gold standard' model of reproducible osteomyelitis capable of experimental manipulation for up to 6 months. Thus established as a standard for the study of bone infection, the model of Norden and Kennedy is used or modified by others. ${ }^{196-205}$

Careful interrogation of studies citing Norden and Kennedy reveal that a number incorrectly interpret the fundamental aspects of the design and thus caution must be adopted in the interpretation of their results. ${ }^{189-207}$ In an additional example of how miscitations are propogated through scientific literature, Moriarty $e t a l^{208}$ incorrectly identify their methodology as that of Norden and Kennedy due in part to the earlier miscitation of Melcher et al. It is imperative that designers of future rabbit bone infection models are cognisant of these errors in citations in order to allow for successful comparison of experimental findings.

Andriole et al ${ }^{183} 209$ developed the work of Norden and Kennedy by extending the study period and incorporating the use of intramedullary nails in the study arms thus using the foreign body effect and enhancing its clinical applicability. Of note, the investigators found that in control animals exposed to inoculation with $S$ aureus only, no osteomyelitis developed. In contrast, both groups of animals with either fracture or intramedullary nail or nailing alone developed osteomyelitis with the same dose as the controls. In addition, a second study ${ }^{209}$ demonstrated that the dose required to produce osteomyelitis in the intervention groups was 100 times less than that required in controls. The value of these studies is the length of the clinical course and the demonstration of the impact of intramedullary devices on osteomyelitis. Of note, no sclerosant is used and the fractures are produced by a three-point bending clamp in a closed fashion. Both the work of Norden and Kennedy and Andriole et al thus advanced the animal modelling of osteomyelitis and informed the methodology of subsequent studies. Both designs however have inherent limitations in application to osteomyelitis research due to the absence of soft tissue trauma, which is a key feature and prognostic indicator with significant limb injury.

A study that at first seems to address these limitations is that of Friedrich and Klaue. ${ }^{182}$ Assessing the impact of fixation rigidity on the incidence of osteomyelitis following open fracture, Friedrich and Klaue used compression plates and intramedullary nails to stabilise contaminated fractures. Their results indicate that contaminated fractures stabilised rigidly demonstrate a clinical path similar to that of non-contaminated fractures similarly fixed and that contaminated fractures fixed with relative stability 
have a greater risk of developing osteomyelitis. Their study design however is poor and allocation to groups and detail of end points are lacking, leading to the questioning of the validity of their findings, despite their apparent clinical application.

The concerns over the lack of applicability to open fractures of the models of Norden and Kennedy ${ }^{195}$ and Andriole et $a l^{183209}$ are highlighted by Worlock et al ${ }^{188}$ in the introduction to their model of post-traumatic osteomyelitis where the use of sclerosant and percutaneous inoculum with no soft tissue trauma and fracture is likened more to a model of haematogenous osteomyelitis than that of traumatic origin. While the model of Andriole et al does incorporate fixation and fracture in its design, soft tissue trauma does not feature and the inoculation point is distant to the site of fracture.

Using the fracture model of Ashhurst's group, ${ }^{186}$ Worlock et $a l^{188}$ performed an open fracture followed by intramedullary nailing of the tibia. In addition to the use of an open fracture by osteotomy, this study advanced the modelling of open fracture by inoculating the fracture site directly, a direct contrast to previous work. They conclude that their model uses animals which are relatively cheap and easily available and the instrumentation required is easily adapted from standard surgical practice. In addition, they were able to reproducibly induce osteomyelitis with no systemic side effects and in contrast to many previous studies, all animals survived. This model benefits from its ability to more closely replicate bacterial contamination at a fracture site and it forms the basis for a number of subsequent studies of therapeutic manipulation of fixation devices for potentially infected fractures ${ }^{210-212}$ and also for studies in which no fracture occurs but direct device infection is enabled by the technique described. ${ }^{213-215}$ In addition, Worlock et $a l^{216}$ used their model to assess the impact of antibiotics on subsequent infection in open fractures and also carried out a key study relating the stability of fracture fixation to ultimate complication by infection-essentially a more robust investigation than that performed earlier by Friedrich and Klaue ${ }^{182}$ but yielding similar findings of decreased post-traumatic osteomyelitis in contaminated fractures that are rigidly stabilised.

Further to the establishment of post-traumatic osteomyelitis as detailed by Worlock et al, ${ }^{188}$ the impact of implants, bone cement and bone wax in osteomyelitis models is also addressed in the rabbit. ${ }^{217-229}$ Current researchers planning study designs should be aware that as with Norden and Kennedy, the model of Nijhof's group has also been incorrectly cited by Jia et $a l^{230}$ in their study of the prophylactic effects of platelet-leucocyte gel in osteomyelitis by omitting cement from their method, obviously an inaccurate model citation.

In contrast to murine modelling, the investigation of soft tissue trauma in rabbits is sparse. There are no controlled models of open muscle trauma in the rabbit and only one closed study is reported. Zhang et $a l^{231}$ used MRI to quantify muscle damage following closed crush injury in New Zealand white rabbits. Their description of injury mechanism is limited, however: 'Then, their right hind limbs were fixed with wooden splints and crushed with $25 \mathrm{~kg}$ heavy weight'. ${ }^{231}$ The only series describing experimental open muscle trauma in the rabbit are military studies from the Vietnam War period. Rutherford et $a l^{232}$ describe the use of a compound soft tissue injury of the buttock region of rabbits in establishing a model of experimental clostridial wounds. Following excision of a full thickness skin flap, non-standardised lacerations were created in the gluteal musculature, down to bone and the incised muscle strips then crushed sequentially with artery forceps. The wounds were then contaminated by soil sourced from the under surface of a motor car. These uncontrolled experiments resulted in significant mortality both through extensive debridement, including disarticulation at the hip, and also from the effects of gas gangrene. Of note from these experiments however is the effect of early debridement in decreasing mortality and, of particular interest, the increased mortality associated with late, as opposed to simply delayed, debridement. In addition, the administration of topical antibiotics was shown to extend the window in which debridement may influence mortality.

The rudimentary model used by Rutherford et $a l^{232}$ was subsequently chosen by Matsumoto et $a l^{233}$ to study the effect of various soil contaminants and the impact of topical antibiotics. In a geographical study, Matsumoto et $a l^{233}$ collected soil samples from swamplands, fertilised farmlands and more arid beach areas around Vietnam during the conflict. The rabbits were prepared as in the model of Rutherford et al and a sample of soil applied to the wound. While the methodology is poor and outcomes unclear, the difference in mortality of the rabbits is marked. Reflecting experience from current conflicts ${ }^{234}$ and that seen in the original description of war wound bacteriological profiles, ${ }^{235}$ the nature of soil influences the bacterial burden of the war wound with wounds occurring in jungle, swamp and fertile farmland associated with greater morbidity than those from more arid climates.

Having established the model of soil samples from conflict zones, Matsumoto et al ${ }^{236-240}$ went on to investigate the application of topical and systemic antibiotics to these wounds in a series of subsequent studies. Refining the methodology slightly, they introduced soil samples and also a known quantity of polymicrobial bacterial suspension to the wounds. Of interest, in these studies guinea pigs were also used for the model; however, no justification for this is made. While suffering from considerable inadequacies in method and animal welfare, these papers demonstrate the proposed benefit of early application of topical antibiotic to combat wounds, which is in contrast to clinical observation from World War II. ${ }^{241}$ The model allowed early experimental contamination with one or more organisms associated with conflict wounds and while its methodological flaws limit its use for modern extremity trauma research, it has value as a basis from which to design animal models of standardised injury and contamination.

\section{SUMMARY}

The conflicts in Iraq and Afghanistan have refocused attention on combat casualty care and in particular the impact of farforward resuscitation, prompt evacuation, haemorrhage control and time limited surgery on patient outcome.

Despite these improvements, a burden of significant extremity trauma remains in those surviving combat injury. This patient cohort is a result, in part, of increasing survival but is also due to the nature of current combat wounding. Injury by gunshot has been eclipsed by explosive devices with its late extremity complications of skin coverage, fracture stabilisation and infection and there remains a need to optimise through animal modelling the management of these disabling injuries. Simple, soft tissue wounding based on velocity and studies of smooth projectile passage through muscle and gelatin have limited relevance to modern conflict wounding patterns.

The concept of tissue injury, albeit at a microscopic level, distant to the passage of a projectile raised in swine models following the Vietnam conflict remains unanswered. This is particularly of relevance to the nerve injuries seen from recent conflict and further in vivo work would be of value to investigate this phenomenon. 
Non-porcine large animal GSW studies also have flaws in their design that have influenced current military surgical doctrine, particularly notable in terms of erroneous recommendations for debridement extent. Such flaws limit the ability to generalise many of the most cited models to contemporary conflict injury. Models of short duration, high-energy, nonprojectile, contaminated extremity injury most representative of current wounding are not seen in large animals.

This lack of complex, contaminated wound models in combination with adherence to the principles of replacement, refinement and reduction has led to the use of small animals such as rats and mice to construct future models of complex military extremity injury. Although murine models are widely used in musculoskeletal research, this review has highlighted limitations in available murine models applicable to military complex extremity trauma.

Murine bone morphology and remodelling raise concerns regarding generalisation to clinical practice both in terms of bone healing and regarding methods of osteosynthesis. Controlled models investigating isolated aspects of fracture initiation, healing and management of contaminated bony defects are available in rats and mice. Studies of compound bone and soft tissue trauma are, by contrast, sparse and where reported are characterised by uncontrolled muscle crushing injury. Controlled soft tissue damage and contamination have not been carried out in rats or mice. The murine models therefore are limited by scale and, to date, fail to generate a model of sufficient compound injury or contamination to have military relevance.

In contrast to the murine models, there is limited evidence for suitability of the guinea pig in the investigation of fracture initiation or management. In addition, while associated with experiments that link bacterial contamination to infection and subsequently influenced the rationale for open fracture management, these are characterised by a lack of control of wounding. Also, the majority of guinea pig studies use the paraspinal musculature in their models, not the extremity, and so generalisation of tissue contamination and healing from these models to modern complex extremity injuries is threatened.

The largest of the small animal models used for the investigation of fracture initiation, healing, contamination and osteomyelitis is the rabbit. As with the murine and guinea pig models, rabbit musculoskeletal experimentation is widespread and the New Zealand white rabbits in particular are accepted throughout healthcare research as a disease and injury model. In comparison to the murine and guinea pig models, the rabbit benefits from increased size and, in particular, more clinically relevant bone healing and ease of osteosynthesis. Rabbit fracture models of the tibia, radius and ulna are abundant and contamination to produce infection either as a percutaneously introduced haematogenous model or one reflective of post-traumatic osteomyelitis is available. These models all use $S$ aureus which is the predominant organism associated with late battlefield wound infection sequelae.

Initial fracture fixation options in the rabbit were rudimentary but currently interlocked intramedullary nails, dynamic compression plates and external fixators are available for fracture stabilisation, although the performance of these devices in the presence of contamination is not reported. In addition, where rabbit models are lacking is in the controlled delivery of a highenergy, short duration muscle injury and its subsequent contamination.

Extremity ballistic injury is unique and the literature intended to guide its management is commonly misinterpreted. In order to care for those injured in conflict, allow debate and the design of preclinical studies, clinicians must be able to identify key in vivo studies, understand their weaknesses and resist the propagation of miscited and misunderstood ballistic dogma.

In order to thus inform military clinicians, we have provided the only inclusive critical overview of key studies of relevance to military extremity injury. In addition, the non-ballistic studies of limb injury, stabilisation and contamination that will form the basis from which future small animal extremity studies are constructed are presented. With an awareness of the legacy of military wound models and an insight into available generic models of extremity injury and contamination, research teams are well placed to optimise future military extremity injury management.

Contributors The planning, conduct and reporting of the work described in this article were equally shared among the authors.

Competing interests None.

Provenance and peer review Not commissioned; externally peer reviewed.

\section{REFERENCES}

1 Covey DC. Combat orthopaedics: a view from the trenches. J Am Acad Orthop Surg 2006;14(10 Suppl):S10-17

2 Cross JD, Ficke JR, Hsu JR, et al. Battlefield orthopaedic injuries cause the majority of long-term disabilities. J Am Acad Orthop Surg 2011;19(Suppl 1):S1-7.

3 Owens BD, Kragh JF Jr, Macaitis J, et al. Characterization of extremity wounds in operation iraqi freedom and operation enduring freedom. J Orthop Trauma 2007:21:254-7.

4 Murray CK. Infectious disease complications of combat-related injuries. Crit Care Med 2008;36(7 Suppl):S358-64

5 Tong MJ. Septic complications of war wounds. JAMA 1972;219:1044-7.

6 Zapor MJ, Moran KA. Infectious diseases during wartime. Curr Opin Infect Dis 2005; 18:395-9.

7 Murray CK, Wilkins K, Molter NC, et al. Infections complicating the care of combat casualties during operations iraqi freedom and enduring freedom. J Trauma 2011;71(1 Suppl):S62-73.

8 MacKenzie EJ, Bosse MJ, Kellam JF, et al. Characterization of patients with high-energy lower extremity trauma. J Orthop Trauma 2000;14:455-66.

9 Eardley WGP. The literature review. In: Page P, Carr J, Eardley WGP, et al., eds. An introduction to clinical research. 1st edn. Oxford: Oxford University Press, 2012:1-11.

10 Alam HB. Advances in resuscitation strategies. Int I Surg 2011;9:5-12.

11 Mapstone J, Roberts I, Evans P. Fluid resuscitation strategies: A systematic review of animal trials. J Trauma 2003;55:571-89.

12 Stern SA. Low-volume fluid resuscitation for presumed hemorrhagic shock: Helpful or harmful? Curr Opin Crit Care 2001;7:422-30.

13 Garner J, Watts S, Parry C, et al. Prolonged permissive hypotensive resuscitation is associated with poor outcome in primary blast injury with controlled hemorrhage. Ann Surg 2010;251:1131-9.

14 Kirkman E, Watts $S$, Cooper $G$. Blast injury research models. Philos Trans $R$ Soc Lond B Biol Sci 2011;366:144-59.

15 Alam HB, Bice LM, Butt MU, et al. Testing of blood products in a polytrauma model: Results of a multi-institutional randomized preclinical trial. J Trauma 2009:67:856-64.

16 Sapsford W, Watts S, Cooper G, et al. Recombinant activated factor VII increases survival time in a model of incompressible arterial hemorrhage in the anesthetized pig. J Trauma 2007;62:868-79.

17 Mitra B, Mori A, Cameron PA, et al. Fresh frozen plasma (FFP) use during massive blood transfusion in trauma resuscitation. Injury 2010;41:35-9.

18 White JM, Cannon JW, Stannard A, et al. Direct vascular control results in less physiologic derangement than proximal aortic clamping in a porcine model of noncompressible extrathoracic torso hemorrhage. J Trauma 2011;71:1278,86; discussion 1286-7.

19 White JM, Cannon JW, Stannard A, et al. Endovascular balloon occlusion of the aorta is superior to resuscitative thoracotomy with aortic clamping in a porcine model of hemorrhagic shock. Surgery 2011;150:400-9.

20 White JM, Cannon JW, Stannard A, et al. A porcine model for evaluating the management of noncompressible torso hemorrhage. J Trauma 2011;71(1 Suppl): S131-8.

21 Granville-Chapman J, Jacobs N, Midwinter MJ. Pre-hospital haemostatic dressings: A systematic review. Injury 2011;42:447-59.

22 DeMuth WE Jr. Bullet velocity as applied to military rifle wounding capacity. J Trauma 1969;9:27-38.

23 DeMuth WE Jr. Bullet velocity makes the difference. J Trauma 1969:9:642-3. 
24 DeMuth WE Jr. High velocity bullet wounds of the thorax. Am J Surg 1968; 115:616-25.

25 DeMuth WE Jr. Bullet velocity and design as determinants of wounding capability: An experimental study. J Trauma 1966;6:222-32.

26 DeMuth WE Jr, Smith JM. High-velocity bullet wounds of muscle and bone: The basis of rational early treatment. J Trauma 1966;6:744-55.

27 Dimond FC Jr, Rich NM. M-16 rifle wounds in vietnam. J Trauma 1967; 7:619-25.

28 King KF. Orthopaedic aspects of war wounds in south vietnam. J Bone Joint Surg Br 1969:51:112-17.

29 Santucci RA, Chang YJ. Ballistics for physicians: Myths about wound ballistics and gunshot injuries. J Urol 2004;171:1408-14.

30 Fackler ML, Dougherty PJ. Theodor Kocher and the scientific foundation of wound ballistics. Surg Gynecol Obstet 1991;172:153-60.

31 Harvey EN, McMillen JH. An experimental study of shock waves resulting from the impact of high velocity missiles on animal tissues. J Exp Med 1947:85:321-8.

32 Schantz B. Is the missile wound a model suitable for general trauma studies? Acta Chir Scand 1982;508(Suppl):159-66.

33 Berlin R, Gelin LE, Janzon B, et al. Local effects of assault rifle bullets in live tissues. Acta Chir Scand 1976;459(Suppl):1-76.

34 Dahlgren B, Berlin $\mathrm{R}$, Janzon B, et al. The extent of muscle tissue damage following missile trauma one, six and twelve hours after the infliction of trauma, studied by the current method of debridement. Acta Chir Scand 1979;489 (Suppl):137-44.

35 Almskog BA, Haljamae $H$, Nordstrom $G$, et al. Effects of penicillin $G$ on local metabolic changes in skeletal muscle following high velocity missile injury. Eur Surg Res 1984;16:194-200.

36 Berlin $\mathrm{R}$, Janzon $B$, Rybeck $B$, et al. Local effects of assault rifle bullets in live tissues. part II. further studies in live tissues and relations to some simulant media. Acta Chir Scand 1977;477(Suppl):5-48.

37 Holmstrom A, Larsson J, Lewis DH. Metabolic changes in skeletal muscle following high-energy trauma. Acta Chir Scand 1983;149:729-34.

38 Holmstrom A, Lund N, Lewis DH. Local skeletal muscle surface oxygen pressure fields after high-energy trauma. Microcirc Endothelium Lymphatics 1985:2:293-311.

39 Holmstrom A, Lewis DH. Regional blood flow in skeletal muscle after high-energy trauma. An experimental study in pigs, using a new laser doppler technique and radioactive microspheres. Acta Chir Scand 1983;149:453-8.

40 Oberg PA, Nilsson GE, Tenland T, et al. Use of a new laser doppler flowmeter for measurement of capillary blood flow in skeletal muscle after bullet wounding. Acta Chir Scand 1979;489(Suppl):145-50.

41 Janzon B, Seeman T. Muscle devitalization in high-energy missile wounds, and its dependence on energy transfer. J Trauma 1985:25:138-44

42 Albreht M, Scepanovic D, Ceramilac A, et al. Experimental soft tissue wounds caused by standard military rifles. Acta Chir Scand 1979:489(Suppl):185-98.

43 Fackler ML, Malinowski JA. Ordnance gelatin for ballistic studies. detrimental effect of excess heat used in gelatin preparation. Am J Forensic Med Pathol 1988:9:218-19.

44 Swan KG, Swan RC, Levine MG, et al. The U.S. M-16 rifle versus the russian AK-47 rifle. A comparison of terminal ballistics. Am Surg 1983;49:472-6.

45 Charters $A C$ 3rd, Charters AC. Wounding mechanism of very high velocity projectiles. J Trauma 1976;16:464-70.

46 Lindsey D. The idolatry of velocity, or lies, damn lies, and ballistics. J Trauma 1980;20:1068-9.

47 Fackler ML, Surinchak JS, Malinowski JA, et al. Wounding potential of the russian AK-74 assault rifle. J Trauma 1984:24:263-6.

48 Fackler ML, Malinowski JA. Internal deformation of the AK-74; a possible cause for its erratic path in tissue. J Trauma 1988;28(1 Suppl):S72-5

49 Fackler ML, Bellamy RF, Malinowski JA. A reconsideration of the wounding mechanism of very high velocity projectiles-importance of projectile shape. I Trauma 1988;28(1 Suppl):S63-7.

50 Fackler ML, Bellamy RF, Malinowski JA. Wounding mechanism of projectiles striking at more than $1.5 \mathrm{~km} / \mathrm{sec}$ J Trauma 1986;26:250-4.

51 Fackler ML, Surinchak JS, Malinowski JA, et al. Bullet fragmentation: A major cause of tissue disruption. J Trauma 1984;24:35-9.

52 Fackler ML. The U.S. M-16 rifle versus the russian AK-74 rifle. Am Surg 1984;50:515-6.

53 Fackler ML, Breteau JP, Courbil LJ, et al. Open wound drainage versus wound excision in treating the modern assault rifle wound. Surgery 1989;105:576-84.

54 Tikka S, Cederberg A, Levanen J, et al. Local effects of three standard assault rifle projectiles in live tissue. Acta Chir Scand 1982;508(Suppl):61-77.

55 Bowyer GW, Cooper GJ, Rice P. Small fragment wounds: Biophysics and pathophysiology. J Trauma 1996;40(3 Suppl):S159-64

56 Mellor SG, Cooper GJ, Bowyer GW. Efficacy of delayed administration of benzylpenicillin in the control of infection in penetrating soft tissue injuries in war. J Trauma 1996:40(3 Suppl):S128-34.

57 Bowyer GW. Management of small fragment wounds: Experience from the afghan border. J Trauma 1996:40(3 Suppl):S170-2.
58 Bowyer GW. Management of small fragment wounds in modern warfare: A return to hunterian principles? Ann R Coll Surg Engl 1997;79:175-82.

59 Hill PF, Edwards DP, Bowyer GW. Small fragment wounds: Biophysics, pathophysiology and principles of management. J R Army Med Corps 2001:147:41-51.

60 Suneson A, Hansson HA, Seeman T. Pressure wave injuries to the nervous system caused by high-energy missile extremity impact: Part I. local and distant effects on the peripheral nervous system-a light and electron microscopic study on pigs. J Trauma 1990;30:281-94.

61 Suneson A, Hansson HA, Seeman T. Pressure wave injuries to the nervous system caused by high-energy missile extremity impact: Part II. distant effects on the central nervous system-a light and electron microscopic study on pigs. J Trauma 1990;30:295-306

62 Fackler ML, Peters CE. Ascribing local, regional, and distant injuries to the sonic pressure wave. J Trauma 1989;29:1455

63 Fackler ML. Gunshot wound review. Ann Emerg Med 1996:28:194-203.

64 Bellamy RF, Zajtchuk R. The physics and biophysics of wound ballistics. In: Zajtchuk R, Jenkins DP, Bellamy RF, Quick CM, eds. Textbook of Military Medicine : Conventional warfare-ballistic blast and burn injuries 1st edn. United states of America: Department of the Army, 1991:107-62.

65 Matheson JM. Infection in missle wounds. Ann R Coll Surg Engl 1968; 42:347-66

66 Rybeck B. Missile wounding and hemodynamic effects of energy absorption. Acta Chir Scand 1974;450(Suppl):1-32.

67 Hopkinson DA, Watts JC. Studies in experimental missile injuries of skeletal muscle. Proc $R$ Soc Med 1963;56:461-8.

68 Dziemain AJ, Mendelson JA, Lindsey D. Comparison of the wounding characteristics of some commonly encountered bullets. J Trauma 1961;1:341-53.

69 Thoresby FP, Watts JC. Gas gangrene of the high-velocity missile wound. Br J Surg 1967:54:25-9.

70 Owen-Smith MS. Antibiotics and antitoxin therapy in the prophylaxis of experimental gas gangrene. Br J Surg 1968;55:43-5.

71 Owen-Smith MS, Matheson JM. Successful prophylaxis of gas gangrene of the high-velocity missile wound in sheep. Br J Surg 1968;55:36-9.

72 Powers DB, Robertson OB. Ten common myths of ballistic injuries. Oral Maxillofac Surg Clin North Am 2005:17:251-9.

73 Fackler ML. Wound ballistics. A review of common misconceptions. JAMA 1988;259:2730-6.

74 Dana SE, DiMaio VJM. Gunshot trauma. In: Payne-James J, Busuttil A, Smock W eds. Forensic Medicine 1st edn. United Kingdom: Greenwich Medical Media Ltd, 2003: 149-68.

75 Court-Brown C, McQueen M, Tornetta P 3rd. Trauma. 1st edn. Philadelphia, PA: Lippincott: Williams \& Wilkins, 2006.

76 Carr NJ, Gallico G. Soft tissue injuries and management about the knee. In: Siliski JM, eds. Traumatic disorders of the knee. 1st edn. New York: Springer-Verlag, 1994:47-63.

77 Pavletic MM. Atlas of small animal wound management and reconstructive surgery 3rd edn. Hoboken, NJ: Wiley-Blackwell, 2010.

78 Clasper JC, Parker SJ, Simpson AH, et al. Contamination of the medullary canal following pin-tract infection. J Orthop Res 1999;17:947-52.

79 Clasper JC, Stapley SA, Bowley DM, et al. Spread of infection, in an animal model, after intramedullary nailing of an infected external fixator pin track. J Orthop Res 2001;19:155-9.

80 Clasper JC, Cannon LB, Stapley SA, et al. Fluid accumulation and the rapid spread of bacteria in the pathogenesis of external fixator pin track infection. Injury 2001:32:377-81.

81 Hill PF, Clasper JC, Parker SJ, et al. Early intramedullary nailing in an animal model of a heavily contaminated fracture of the tibia. J Orthop Res 2002;20:648-53.

82 Curtis MJ, Brown PR, Dick JD, et al. Contaminated fractures of the tibia: A comparison of treatment modalities in an animal model. J Orthop Res 1995;13:286-95.

83 Svoboda SJ, Bice TG, Gooden HA, et al. Comparison of bulb syringe and pulsed lavage irrigation with use of a bioluminescent musculoskeletal wound model. J Bone Joint Surg Am 2006:88:2167-74.

84 Svoboda SJ, Owens BD, Gooden HA, et al. Irrigation with potable water versus normal saline in a contaminated musculoskeletal wound model. J Trauma 2008;64:1357-9.

85 Owens BD, White DW, Wenke JC. Comparison of irrigation solutions and devices in a contaminated musculoskeletal wound survival model. J Bone Joint Surg Am 2009:91:92-8.

86 Owens BD, Wenke JC. Early wound irrigation improves the ability to remove bacteria. J Bone Joint Surg Am 2007;89:1723-6.

87 Stinner DJ, Noel SP, Haggard WO, et al. Local antibiotic delivery using tailorable chitosan sponges: The future of infection control? J Orthop Trauma 2010;24:592-7.

88 Branstetter JG, Jackson SR, Haggard WO, et al. Locally-administered antibiotics in wounds in a limb. J Bone Joint Surg Br 2009;91:1106-9.

89 Lalliss SJ, Stinner DJ, Waterman SM, et al. Negative pressure wound therapy reduces pseudomonas wound contamination more than staphylococcus aureus. $J$ Orthop Trauma 2010:24:598-602. 
90 Stinner DJ, Waterman SM, Masini BD, et al. Silver dressings augment the ability of negative pressure wound therapy to reduce bacteria in a contaminated open fracture model. J Trauma 2011;71(1 Suppl):S147-50.

91 Salgado CJ, Jamali AA, Mardini S, et al. A model for chronic osteomyelitis using staphylococcus aureus in goats. Clin Orthop Relat Res 2005;(436):246-50.

92 Nelson BJ, DeBerardino TM, Brooks DE, et al. The efficacy of steel, silver-coated, and chlorhexidine/chloroxylenol-coated external fixator pins in preventing pin tract infections in a caprine model. 45th annual meeting, orthopaedic research society, february 1-4, 1999, anaheim, california; 1st-4th February 1999; Orthopaedic Research Society. 1999

93 DeJong ES, DeBerardino TM, Brooks DE, et al. Antimicrobial efficacy of external fixator pins coated with a lipid stabilized hydroxyapatite/chlorhexidine complex to prevent pin tract infection in a goat model. J Trauma 2001;50:1008-14.

94 Voos K, Rosenberg B, Fagrhi M, et al. Use of a tobramycin-impregnated polymethylmethacrylate pin sleeve for the prevention of pin-tract infection in goats. J Orthop Trauma 1999;13:98-101.

95 van der Borden AJ, van der Werf $\mathrm{H}$, van der Mei HC, et al. Electric current-induced detachment of staphylococcus epidermidis biofilms from surgica stainless steel. App/ Environ Microbiol 2004;70:6871-4.

96 Warme WJ, Brooks D, Carpenter L, et al. External fixator pin tract infection model in the caprine (goat) tibia: A randomized, prospective, blinded study. Am J Orthop (Belle Mead NJ) 2004;33:447-51.

97 Russell WMS, Burch RL. The principles of humane experimental technique. 1st edn. London: Methuen, 1959.

98 Hrapkiewicz K, Medina L, eds. Clinical laboratory animal medicine. 3rd edn. Oxford: United Kingdom: Blackwell, 2007.

99 Perren SM, Huggler A, Russenberger $M$, et al. The reaction of cortical bone to compression. Acta Orthop Scand 1969;125(Suppl):19-29.

100 Rüedi TP, Murphy WM. AO principles of fracture management. 1st edn. Switzerland: Thieme, 2000.

101 Allgower M, Perren S, Matter P. A new plate for internal fixation-the dynamic compression plate (DCP). Injury 1970;2:40-7.

102 Hiltunen A, Vuorio E, Aro HT. A standardized experimental fracture in the mouse tibia. J Orthop Res 1993;11:305-12.

103 Schindeler A, Morse A, Harry L, et al. Models of tibial fracture healing in normal and Nf1-deficient mice. J Orthop Res 2008;26:1053-60.

104 Bonnarens F, Einhorn TA. Production of a standard closed fracture in laboratory animal bone. J Orthop Res 1984;2:97-101.

105 Marturano JE, Cleveland BC, Byrne MA, et al. An improved murine femur fracture device for bone healing studies. J Biomech 2008;41:1222-8.

106 Holstein JH, Menger MD, Culemann U, et al. Development of a locking femur nail for mice. J Biomech 2007:40:215-19.

107 Schmidmaier G, Wildemann B, Melis B, et al. Development and characterization of a standard closed tibial fracture model in the rat. Eur J Trauma Emerg Surg 2004;30:35-42.

108 Holstein JH, Matthys R, Histing T, et al. Development of a stable closed femoral fracture model in mice. J Surg Res 2009;153:71-5.

109 Garcia P, Holstein JH, Maier S, et al. Development of a reliable non-union model in mice. J Surg Res 2008;147:84-91.

110 Garcia P, Holstein JH, Histing $T$, et al. A new technique for internal fixation of femoral fractures in mice: Impact of stability on fracture healing. J Biomech 2008;41:1689-96.

111 Matthys R, Perren SM. Internal fixator for use in the mouse. Injury 2009;40(Suppl 4):S103-9.

112 Histing T, Garcia P, Matthys R, et al. An internal locking plate to study intramembranous bone healing in a mouse femur fracture model. J Orthop Res 2010;28:397-402.

113 Bhandari $\mathrm{M}$, Schemitsch $\mathrm{EH}$. Bone formation following intramedullary femoral reaming is decreased by indomethacin and antibodies to insulin-like growth factors. J Orthop Trauma 2002;16:717-22.

114 Cheung KM, Kaluarachi K, Andrew G, et al. An externally fixed femoral fracture model for mice. J Orthop Res 2003;21:685-90.

115 Thompson Z, Miclau T, Hu D, et al. A model for intramembranous ossification during fracture healing. J Orthop Res 2002:20:1091-8.

116 Miclau T, Lu C, Thompson Z, et al. Effects of delayed stabilization on fracture healing. J Orthop Res 2007;25:1552-8.

117 Rontgen V, Blakytny $\mathrm{R}$, Matthys $\mathrm{R}$, et al. Fracture healing in mice under controlled rigid and flexible conditions using an adjustable external fixator. J Orthop Res 2010;28:1456-62

118 Urist MR, McLean FC. Calcification in the callus in healing fractures in normal rats. JBone Joint Surg 1941:23:1-16.

119 Jackson RW, Reed CA, Israel JA, et al. Production of a standard experimental fracture. Can J Surg 1970;13:415-20.

120 Sarmiento A, Schaeffer JF, Beckerman $L$, et al. Fracture healing in rat femora as affected by functional weight-bearing. J Bone Joint Surg Am 1977;59:369-75.

121 Probst $A$, Jansen $H$, Ladas $A$, et al. Callus formation and fixation rigidity: $A$ fracture model in rats. J Orthop Res 1999:17:256-60.

122 Mark $\mathrm{H}$, Nilsson A, Nannmark U, et al. Effects of fracture fixation stability on ossification in healing fractures. Clin Orthop Relat Res 2004:245-50.
123 Greiff J. A method for the production of an undisplaced reproducible tibial fracture in the rat. Injury 1978;9:278-81.

124 Tatari $\mathrm{H}$, Fidan M, Erbil G, et al. A new device to produce a standardized experimental fracture in the rat tibia. Saudi Med J 2007;28:866-71.

125 Claes L, Blakytny R, Gockelmann M, et al. Early dynamization by reduced fixation stiffness does not improve fracture healing in a rat femoral osteotomy model. J Orthop Res 2009;27:22-7.

126 Jarvinen M, Sorvari T. Healing of a crush injury in rat striated muscle. 1. description and testing of a new method of inducing a standard injury to the calf muscles. Acta Pathol Microbiol Scand A 1975;83:259-65.

127 Akimau P, Yoshiya K, Hosotsubo $\mathrm{H}$, et al. New experimental model of crush injury of the hindlimbs in rats. J Trauma 2005;58:51-8.

128 Filippin LI, Cuevas MJ, Lima E, et al. Nitric oxide regulates the repair of injured skeletal muscle. Nitric Oxide 2011:24:43-9.

129 Efeito do uso de corticóide em tendões previamente traumatizados: Estudo experimental [Internet].: Revista Brasileira De Ortopedia; 1996 [updated March 1996]. http://www.rbo.org.br/materia.asp?mt=1057\&idldioma=1 (accessed 1 May 2012).

130 Rubinstein I, Abassi Z, Coleman R, et al. Involvement of nitric oxide system in experimental muscle crush injury. J Clin Invest 1998;101:1325-33.

131 Schaser KD, Vollmar B, Menger MD, et al. In vivo analysis of microcirculation following closed soft-tissue injury. J Orthop Res 1999;17:678-85.

132 Beiner JM, Jokl P, Cholewicki J, et al. The effect of anabolic steroids and corticosteroids on healing of muscle contusion injury. Am J Sports Med 1999;27:2-9.

133 Crisco JJ, Jokl P, Heinen GT, et al. A muscle contusion injury model. biomechanics, physiology, and histology. Am J Sports Med 1994;22:702-10.

134 Crisco JJ, Hentel KD, Jackson WO, et al. Maximal contraction lessens impact response in a muscle contusion model. J Biomech 1996;29:1291-6.

135 Claes L, Maurer-Klein N, Henke T, et al. Moderate soft tissue trauma delays new bone formation only in the early phase of fracture healing. J Orthop Res 2006;24:1178-85.

136 Khattak MJ, Ahmad T, Rehman R, et al. Muscle healing and nerve regeneration in a muscle contusion model in the rat. J Bone Joint Surg Br 2010;92-B:894-9.

137 McBrier NM, Neuberger T, Okita N, et al. Reliability and validity of a novel muscle contusion device. J Ath/ Train 2009;44:275-8.

138 Rushton JL, Davies I, Horan MA, et al. Production of consistent crush lesions of murine skeletal muscle in vivo using an electromechanical device. J Anat 1997:190:417-22.

139 Bunn JR, Canning J, Burke G, et al. Production of consistent crush lesions in murine quadriceps muscle-a biomechanical, histomorphological and immunohistochemical study. J Orthop Res 2004:22:1336-44.

140 Utvag SE, Grundnes O, Rindal DB, et al. Influence of extensive muscle injury on fracture healing in rat tibia. J Orthop Trauma 2003:17:430-5.

141 Fink E, Fortin D, Serrurier B, et al. Recovery of contractile and metabolic phenotypes in regenerating slow muscle after notexin-induced or crush injury. J Muscle Res Cell Motil 2003;24:421-9.

142 Stratos I, Graff J, Rotter R, et al. Open blunt crush injury of different severity determines nature and extent of local tissue regeneration and repair. J Orthop Res 2010;28:950-7

143 Winkler $T$, von Roth $P$, Matziolis $G$, et al. Time course of skeletal muscle regeneration after severe trauma. Acta Orthop 2011;82:102-11.

144 Kurek JB, Bower JJ, Romanella $M$, et al. The role of leukemia inhibitory factor in skeletal muscle regeneration. Muscle Nerve 1997;20:815-22.

145 McGeachie JK, Grounds MD. Initiation and duration of muscle precursor replication after mild and severe injury to skeletal muscle of mice. an autoradiographic study. Cell Tissue Res 1987;248:125-30.

146 Zak 0, Zak F, Rich R. Experimental staphyloccal osteomyelitis in rats. Abstract Number 530. Interscience Conference on Antimicrobial Agents and Chemotherapy; Chicago, 1981.

147 Rissing JP, Buxton TB, Weinstein RS, et al. Model of experimental chronic osteomyelitis in rats. Infect Immun 1985:47:581-6.

148 Mendel V, Simanowski HJ, Scholz HC, et al. Therapy with gentamicin-PMMA beads, gentamicin-collagen sponge, and cefazolin for experimental osteomyelitis due to staphylococcus aureus in rats. Arch Orthop Trauma Surg 2005; 125:363-8.

149 Power ME, Olson ME, Domingue PA, et al. A rat model of staphylococcus aureus chronic osteomyelitis that provides a suitable system for studying the human infection. J Med Microbiol 1990;33:189-98.

150 Spagnolo N, Greco F, Rossi A, et al. Chronic staphylococcal osteomyelitis: A new experimental rat model. Infect Immun 1993:61:5225-30.

151 Fukushima N, Yokoyama K, Sasahara T, et al. Establishment of rat model of acute staphylococcal osteomyelitis: Relationship between inoculation dose and development of osteomyelitis. Arch Orthop Trauma Surg 2005;125:169-76.

152 Gerhart TN, Roux RD, Hanff PA, et al. Antibiotic-loaded biodegradable bone cement for prophylaxis and treatment of experimental osteomyelitis in rats. J Orthop Res 1993:11:250-5.

153 Lucke M, Schmidmaier G, Sadoni S, et al. A new model of implant-related osteomyelitis in rats. J Biomed Mater Res B Appl Biomater 2003;67:593-602. 
154 Gracia E, Lacleriga A, Monzon M, et al. Application of a rat osteomyelitis model to compare in vivo and in vitro the antibiotic efficacy against bacteria with high capacity to form biofilms. J Surg Res 1998;79:146-53.

155 Monzon M, Garcia-Alvarez F, Lacleriga A, et al. A simple infection model using pre-colonized implants to reproduce rat chronic staphylococcus aureus osteomyelitis and study antibiotic treatment. J Orthop Res 2001;19:820-6.

156 Robinson DA, Bechtold JE, Carlson CS, et al. Development of a fracture osteomyelitis model in the rat femur. J Orthop Res 2011;29:131-7.

157 Lindsey BA, Clovis NB, Smith ES, et al. An animal model for open femur fracture and osteomyelitis: Part I. J Orthop Res 2010;28:38-42.

158 Buxton TB, Travis MT, O'Shea KJ, et al. Low-dose infectivity of staphylococcus aureus (SMH strain) in traumatized rat tibiae provides a model for studying early events in contaminated bone injuries. Comp Med 2005;55:123-8.

159 McPherson JC 3rd, Runner RR, Shapiro B, et al. An acute osteomyelitis model in traumatized rat tibiae involving sand as a foreign body, thermal injury, and bimicrobial contamination. Comp Med 2008;58:369-74.

160 Brown KV, Walker JA, Cortez DS, et al. Earlier debridement and antibiotic administration decrease infection. J Surg Orthop Adv 2010;19:18-22.

161 Guelcher SA, Brown KV, Li B, et al. Dual-purpose bone grafts improve healing and reduce infection. J Orthop Trauma 2011;25:477-82.

162 Li B, Brown KV, Wenke JC, et al. Sustained release of vancomycin from polyurethane scaffolds inhibits infection of bone wounds in a rat femoral segmental defect model. J Control Release 2010;145:221-30.

163 Penn-Barwell JG, Murray CK, Wenke JC. Early antibiotics and debridement independently reduce infection in an open fracture model. J Bone Joint Surg $\mathrm{Br}$ 2012;94:107-12.

164 Kalicke T, Schlegel U, Printzen G, et al. Influence of a standardized closed soft tissue trauma on resistance to local infection. an experimental study in rats. J Orthop Res 2003;21:373-8.

165 Yarboro SR, Baum EJ, Dahners LE. Locally administered antibiotics for prophylaxis against surgical wound infection an in vivo study. J Bone Joint Surg Am 2007;89:929-33.

166 McMurray DN. Guinea pig model of tuberculosis. In: Bloom BR, eds. Tuberculosis: Pathogenesis, protection and control. 1st edn. Washington, USA: American Society for Microbiology, 1994:135.

167 Schluger NW. The pathogenesis of tuberculosis. Am J Respir Cell Mol Biol 2005;32:251-6.

168 Edlich RF, Tsung MS, Rogers W, et al. Studies in management of the contaminated wound. I. technique of closure of such wounds together with a note on a reproducible experimental model. J Surg Res 1968;8:585-92.

169 Kdolsky R, Reihsner R, Beer R. Biomechanical analysis of fracture healing in guinea-pigs. Stud Health Technol Inform 2008;133:141-7.

170 Passl R, Muller C, Zielinski CC, et al. A model of experimental post-traumatic osteomyelitis in guinea pigs. J Trauma 1984;24:323-6.

171 Werner CML, Pierpont Y, Pollak AN. The urgency of surgical debridement in the management of open fractures. J Am Acad Orthop Surg 2008; 16:369-75.

172 Lammers R, Henry C, Howell J. Bacterial counts in experimental, contaminated crush wounds irrigated with various concentrations of cefazolin and penicillin. Am J Emerg Med 2001;19:1-5.

173 Custer J, Edlich RF, Prusak M, et al. Studies in the management of the contaminated wound. $V$. an assessment of the effectiveness of pHisoHex and betadine surgical scrub solutions. Am J Surg 1971;121:572-5.

174 Edlich RF, Madden JE, Prusak M, et al. Studies in the management of the contaminated wound. VI. the therapeutic value of gentle scrubbing in prolonging the limited period of effectiveness of antibiotics in contaminated wounds. Am J Surg 1971;121:668-72.

175 Edlich RF, Prusak M, Panek P, et al. Studies in the management of the contaminated wound. 8. assessment of tissue adhesives for repair of contaminated tissue. Am J Surg 1971;122:394-7.

176 Schauerhamer RA, Edlich RF, Panek $\mathrm{P}$, et al. Studies in the management of the contaminated wound. VII. susceptibility of surgical wounds to postoperative surface contamination. Am J Surg 1971;122:74-7.

177 Edlich RF, Custer J, Madden J, et al. Studies in management of the contaminated wound. 3. assessment of the effectiveness of irrigation with antiseptic agents. Am J Surg 1969;118:21-30.

178 Edlich RF, Rogers W, Kasper G, et al. Studies in the management of the contaminated wound. I. optimal time for closure of contaminated open wounds. II. comparison of resistance to infection of open and closed wounds during healing. Am J Surg 1969;117:323-9.

179 Badia JM, Torres JM, Tur C, et al. Saline wound irrigation reduces the postoperative infection rate in guinea pigs. J Surg Res 1996:63:457-9.

180 Stratford AF, Zoutman DE, Davidson JS. Effect of lidocaine and epinephrine on staphylococcus aureus in a guinea pig model of surgical wound infection. Plast Reconstr Surg 2002;110:1275-9.

181 Oni OOA, Gregg PJ, Morrison C, et al. An investigation of the fracture characteristics of the tibia of mature rabbits. Injury 1988;19:172-6.
182 Friedrich B, Klaue P. Mechanical stability and post-traumatic osteitis: An experimental evaluation of the relation between infection of bone and internal fixation. Injury 1977:9:23-9.

183 Andriole VT, Nagel DA, Southwick WO. A paradigm for human chronic osteomyelitis. J Bone Joint Surg Am 1973;55:1511-15.

184 Dekel S, Lenthall G, Francis M. Release of prostaglandins from bone and muscle after tibial fracture. an experimental study in rabbits. J Bone Joint Surg $\mathrm{Br}$ 1981;63-B:185-9.

185 Rahn BA, Gallinaro P, Baltensperger A, et al. Primary bone healing. an experimental study in the rabbit. J Bone Joint Surg Am 1971;53:783-6.

186 Ashhurst DE, Hogg J, Perren SM. A method for making reproducible experimental fractures of the rabbit tibia. Injury 1982;14:236-42.

187 Park SH, Cassim A, Llinas A, et al. Technique for producing controlled closed fractures in a rabbit model. J Orthop Res 1994:12:732-6.

188 Worlock P, Slack R, Harvey L, et al. An experimental model of post-traumatic osteomyelitis in rabbits. Br J Exp Pathol 1988;69:235-44.

189 Melcher GA, Claudi B, Schlegel U, et al. Influence of type of medullary nail on the development of local infection. an experimental study of solid and slotted nails in rabbits. J Bone Joint Surg Br 1994;76:955-9.

190 Melcher GA, Hauke C, Metzdorf A, et al. Infection after intramedullary nailing: An experimental investigation on rabbits. Injury 1996;27(Suppl 3):SC23-6.

191 LeCronier DJ, Papakonstantinou JS, Gheevarughese V, et al. Development of an interlocked nail for segmental defects in the rabbit tibia. Proc Inst Mech Eng $\mathrm{H}$ 2012;226:330-6.

192 Scheman L, Janota M, Lewin P. the production of experimental osteomyelitis. JAMA 1941;117:1525-9.

193 MITRA RN. Experimental osteomyelitis in rabbits. J Int Coll Surg 1964;41:171-81.

194 Finsterbusch A, Argaman M, Sacks T. Bone and joint perfusion with antibiotics in the treatment of experimental staphylococcal infection in rabbits. J Bone Joint Surg Am 1970;52:1424-32.

195 Norden CW. Experimental osteomyelitis. I. A description of the model. J Infect Dis 1970;122:410-18.

196 Joosten U, Joist A, Gosheger G, et al. Effectiveness of hydroxyapatite-vancomycin bone cement in the treatment of staphylococcus aureus induced chronic osteomyelitis. Biomaterials 2005;26:5251-8.

197 Jacob E, Arendt DM, Brook I, et al. Enzyme-linked immunosorbent assay for detection of antibodies to staphylococcus aureus cell walls in experimental osteomyelitis. J Clin Microbiol 1985;22:547-52.

198 Shirtliff ME, Calhoun JH, Mader JT. Comparative evaluation of oral levofloxacin and parenteral nafcillin in the treatment of experimental methicillin-susceptible staphylococcus aureus osteomyelitis in rabbits. J Antimicrob Chemother 2001;48:253-8.

199 Mader JT, Morrison LT, Adams KR. Comparative evaluation of A-56619, A-56620, and nafcillin in the treatment of experimental staphylococcus aureus osteomyelitis. Antimicrob Agents Chemother 1987;31:259-63.

200 Shirtliff ME, Calhoun JH, Mader JT. Experimental osteomyelitis treatment with antibiotic-impregnated hydroxyapatite. Clin Orthop Relat Res 2002;(401):239-47.

201 Yin L, Lazzarini L, Li F, et al. Comparative evaluation of tigecycline and vancomycin, with and without rifampicin, in the treatment of methicillin-resistant staphylococcus aureus experimental osteomyelitis in a rabbit model. J Antimicrob Chemother 2005;55:995-1002.

202 Van Wingerden GI, Lolans V, Jackson GG. Experimental pseudomonas osteomyelitis: Treatment with sisomicin and carbenicillin. J Bone Joint Surg Am 1974;56:1452-8.

203 Crane LR, Kapdi CC, Wolfe JN, et al. Xeroradiographic, bacteriologic, and pathologic studies in experimental staphylococcus osteomyelitis. Proc Soc Exp Biol Med 1977;156:303-14.

204 Dekel S, Francis MJ. The treatment of osteomyelitis of the tibia with sodium salicylate. an experimental study in rabbits. J Bone Joint Surg $\mathrm{Br}$ 1981;63-B:178-84

205 Mayberry-Carson KJ, Tober-Meyer B, Smith JK. Bacterial adherence and glycocalyx formation in osteomyelitis experimentally induced with staphylococcus aureus. Infect Immun 1984:43:825-33.

206 Horn J, Schlegel U, Krettek C, et al. Infection resistance of unreamed solid, hollow slotted and cannulated intramedullary nails: An in-vivo experimental comparison. $J$ Orthop Res 2005;23:810-15.

207 Efstathopoulos N, Giamarellos-Bourboulis E, Kanellakopoulou K, et al. Treatment of experimental osteomyelitis by methicillin resistant staphylococcus aureus with bone cement system releasing grepafloxacin. Injury 2008;39:1384-90.

208 Moriarty TF, Campoccia D, Nees SK, et al. In vivo evaluation of the effect of intramedullary nail microtopography on the development of local infection in rabbits. Int J Artif Organs 2010;33:667-75.

209 Andriole VT, Nagel DA, Southwick WO. Chronic staphylococcal osteomyelitis: An experimental model. Yale. J Biol Med 1974:47:33-9.

210 Arens $S$, Schlegel U, Printzen $G$, et al. Influence of materials for fixation implants on local infection. an experimental study of steel versus titanium DCP in rabbits. J Bone Joint Surg Br 1996;78:647-51.

211 Fei J, Yu HJ, Pan CJ, et al. Efficacy of a norvancomycin-loaded, PDLLA-coated plate in preventing early infection of rabbit tibia fracture. Orthopedics 2010;33. 
212 Darouiche RO, Farmer J, Chaput C, et al. Anti-infective efficacy of antiseptic-coated intramedullary nails. J Bone Joint Surg Am 1998;80:1336-40.

213 Moriarty TF, Debefve L, Boure L, et al. Influence of material and microtopography on the development of local infection in vivo: Experimental investigation in rabbits. Int J Artif Organs 2009:32:663-70.

214 Johansson A, Lindgren JU, Nord CE, et al. Local plate infections in a rabbit model. Injury 1999;30:587-90.

215 Kalicke T, Schierholz J, Schlegel U, et al. Effect on infection resistance of a local antiseptic and antibiotic coating on osteosynthesis implants: An in vitro and in vivo study. J Orthop Res 2006;24:1622-40.

216 Worlock P, Slack R, Harvey L, et al. The prevention of infection in open fractures: An experimental study of the effect of fracture stability. Injury 1994;25:31-8.

217 Eerenberg JP, Patka P, Haarman HJ, et al. A new model for posttraumatic osteomyelitis in rabbits. J Invest Surg 1994;7:453-65.

218 Wellisz T, An YH, Wen X, et al. Infection rates and healing using bone wax and a soluble polymer material. Clin Orthop Relat Res 2008:466:481-6.

219 Mader JT, Stevens CM, Stevens JH, et al. Treatment of experimental osteomyelitis with a fibrin sealant antibiotic implant. Clin Orthop Relat Res 2002;403:58-72.

220 Aykut S, Ozturk A, Ozkan Y, et al. Evaluation and comparison of the antimicrobia efficacy of teicoplanin- and clindamycin-coated titanium implants: An experimental study. J Bone Joint Surg Br 2010;92:159-63.

221 Darouiche RO, Mansouri MD, Zakarevicz D, et al. In vivo efficacy of antimicrobial-coated devices. J Bone Joint Surg Am 2007;89:792-7.

222 Darouiche RO, Landon GC, Patti JM, et al. Role of staphylococcus aureus surface adhesins in orthopaedic device infections: Are results model-dependent? J Med Microbiol 1997;46:75-9.

223 Sheehan E, McKenna J, Mulhall KJ, et al. Adhesion of staphylococcus to orthopaedic metals, an in vivo study. J Orthop Res 2004;22:39-43.

224 Rodeheaver GT, Rukstalis D, Bono M, et al. A new model of bone infection used to evaluate the efficacy of antibiotic-impregnated polymethylmethacrylate cement. Clin Orthop Relat Res 1983;178:303-11.

225 Giavaresi G, Borsari V, Fini M, et al. Preliminary investigations on a new gentamicin and vancomycin-coated PMMA nail for the treatment of bone and intramedullary infections: An experimental study in the rabbit. J Orthop Res 2008; 26:785-92.

226 Moojen DJ, Vogely HC, Fleer A, et al. No efficacy of silver bone cement in the prevention of methicillin-sensitive staphylococcal infections in a rabbit contaminated implant bed model. J Orthop Res 2009;27:1002-7.
227 Nijhof MW, Stallmann HP, Vogely HC, et al. Prevention of infection with tobramycin-containing bone cement or systemic cefazolin in an animal model. J Biomed Mater Res 2000:52:709-15.

228 Nijhof MW, Dhert WJ, Fleer A, et al. Prophylaxis of implant-related staphylococcal infections using tobramycin-containing bone cement. J Biomed Mater Res 2000;52:754-61.

229 Nijhof MW, Fleer A, Hardus K, et al. Tobramycin-containing bone cement and systemic cefazolin in a one-stage revision. treatment of infection in a rabbit model. J Biomed Mater Res 2001;58:747-53.

230 Jia WT, Zhang CQ, Wang JQ, et al. The prophylactic effects of platelet-leucocyte gel in osteomyelitis: An experimental study in a rabbit model. J Bone Joint Surg $\mathrm{Br}$ 2010;92:304-10.

231 Zhang LY, Ding JT, Wang Y, et al. MRI quantitative study and pathologic analysis of crush injury in rabbit hind limb muscles. J Surg Res 2011;167:e357-63.

232 Rutherford RB, Evans JR, Progrebniak $A$, et al. Experimental clostridial wounds in rabbits. I. the effect of debridement delay, tetanus immunization, and topical antibiotics on the mortality from gas gangrene. J Trauma 1966;6:548-62.

233 Matsumoto T, Hardaway RM 3rd, Dobek AS, et al. Different soils in simulated combat wound. I. vietnam. Mil Med 1967;132:893-5.

234 Scott P, Deye G, Srinivasan A, et al. An outbreak of multidrug-resistant acinetobacter baumannii-calcoaceticus complex infection in the US military health care system associated with military operations in iraq. Clin Infect Dis 2007:44:1577-84.

235 Fleming A. On the bacteriology of septic wounds. Lancet 1915; 186:638-43.

236 Matsumoto T, Hardaway RM 3rd, Dobek AS, et al. Antibiotic topical spray applied in a simulated combat wound. Arch Surg 1967;95:288-94.

237 Matsumoto T, Dobek AS, Kovaric JJ, et al. Topical antibiotic spray in contaminated crush wounds in animals. Mil Med 1968;133:869-86.

238 Matsumoto T, Dobek AS, Kovaric JJ, et al. Topical spray of antibiotics in simulated combat wounds. 3. Time factor between wounding and spray. Arch Surg 1968:97:56-60.

239 Matsumoto T, Dobek AS, Kovaric JJ, et al. Topical spray of antibiotics in simulated combat wounds. IV. Dose factor. Arch Surg 1968;97:61-7.

240 Matsumoto T, Dobek AS. Systemic antibiotic(s) in contaminated crush wound without debridement. Arch Surg 1969;99:103-6.

241 Churchill ED. The surgical management of the wounded in the mediterranean theater at the time of the fall of Rome. Ann Surg 1944;120:268-83. 